\title{
PENERAPAN METODE PRAKTIKUM BERBASIS INKUIRI PADA PELAJARAN FISIKA TOPIK GETARAN DAN GELOMBANG UNTUK MENINGKATKAN HASIL BELAJAR DAN KETERAMPILAN PROSES SAINS SISWA KELAS XI SMAN 1 PRINGGARATA TAHUN PELAJARAN 2018/2019
}

\author{
Nur Shofia Hidayati ${ }^{1}$, L. Ahmad Didik Meiliyadi ${ }^{2}$ dan Yahdi $^{3}$ \\ ${ }^{1}$ Universitas Islam Negeri Mataram, Mataram, 83116, Indonesia \\ Shofia.hidayati25@gmail.com \\ ${ }^{2}$ Program Studi tadris Fisika, Fakultas Tarbiyah dan Keguruan, Universitas Islam Negeri Mataram, Mataram, 83116, \\ Indonesia \\ laludidik@uinmataram.ac.id \\ ${ }^{3}$ Program Studi Tadris kimia, Fakultas Tarbiyah dan Keguruan, Universitas Islam Negeri Mataram, Mataram, 83116, \\ Indonesia \\ Yahdi@uinmataram.ac.id
}

Diajukan: 17 January 2021; Diterima: 22 February 2021; Diterbitkan: 30 April 2021

\begin{abstract}
Abstrak: Tujuan dari penelitian ini adalah untuk mengetahui bagaimana pengaruh penerapan metode praktikum berbasis inkuiri pada pelajaran fisika topik getaran dan gelombang untuk meningkatkan hasil belajar dan keterampilan proses sains siswa kelas XI SMAN 1 Pringgarata. Jenis penelitian yang digunakan adalah Penelitian Tindakan Kelas (PTK). Dimana dalam penelitian ini menggunakan 2 siklus yaitu siklus I dan siklus II. Hal yang diteliti pada penelitian ini adalah aspek kognitif, psikomotorik dan afektif. Aspek kognitif diukur menggunakan tes, aspek psikomotorik diukur menggunakan lembar observasi siswa dan aspek afektif diukur menggunakan angket. Hasil penelitian yang diperoleh pada aspek kognitif pada siklus I dengan rata-rata 81.71 dan pada siklus II dengan rata-rata 91.25. Sedangkan keterampilan proses sains siswa pada aspek psikomotorik dan apektif siswa pada siklus I dengan rata-rata 77.61 dan siklus II 78.20. Berdasarkan hasil penelitian dapat disimpulkan bahwa penerapan metode praktikum berbasis inkuiri pada pelajaran fisika topik getaran dan gelombang dapat meningkatkan hasil belajar dan keterampilan proses sains siswa kelas XI SMAN 1 Pringgarata tahun pelajaran 2018/2019.
\end{abstract}

Kata Kunci: Metode praktikum, Inkuiri, Hasil Belajar, Keterampilan Proses Sains

\begin{abstract}
The purpose of this study was to determine how the application of inquiry-based practicum methods to physics lessons on the topic of vibrations and waves improves learning outcomes and science process skills of class XI students of SMAN 1 Pringgarata. The type of research used is Classroom Action Research (CAR). Where in this study used 2 cycles, namely cycle I and cycle II. The things examined in this study were cognitive, psychomotor and affective aspects. Cognitive aspects were measured using tests, psychomotor aspects were measured using student observation sheets and affective aspects were measured using questionnaires. The results obtained on the cognitive aspect in the first cycle with an average of 81.71 and in the second cycle with an average of 91.25. While the science process skills of students in the psychomotor and affective aspects of students in the first cycle with an average of 77.61 and 78.20 in the second cycle. Based on the results of the study, it can be concluded that the application of inquiry-based practicum methods in physics lessons on the topic of vibrations and waves can improve learning outcomes and science process skills for class XI students of SMAN 1 Pringgarata in the 2018/2019 academic year..
\end{abstract}

Keywords: Practical Methods, Inquiry, Learning Outcomes, Science Process Skills

\section{Pendahuluan}

Pendidikan merupakan usaha sadar dan terencana untuk mewujudkan suasana belajar dan proses pembelajaran supaya peserta didik secara aktif mengembangkan potensi di dalam dirinya untuk memiliki kekuatan spiritual, keagamaan, pengendalian diri, kepribadian, kecerdasan, akhlak mulia, serta keteampilan 
yang diperlukan bagi dirinya, masyarakat dan negara.

Dalam proses pembelajaran, tidak hanya satu dua pelajaran yang akan dipelajari di sekolah, akan tetapi salah satu mata pelajaran yang dipelajari adalah mata pelajaran IPA, yang khususnya dalam IPA tersebut adalah fisika. Sains (IPA) pada hakikatnya merupakan sebuah batang tubuh ilmu pengetahuan ( $a$ body of knowledge), cara berpikir (a way of thingking) dan cara menyelidiki (a way of investigating). Ilmu Pengetahuan Alam (IPA) adalah bagian dari ilmu pegetahuan sains. IPA merupakan bagian dasar dari produk ilmiah, proses ilmiah da sikap ilmiah. Selain dari itu IPA juga dianggap sebagai proses, produk dan prosedur.

Pada umumnya IPA memiliki tiga bagian dasar ilmu yaitu salah satunya adalah fisika. Fisika adalah cabang ilmu pengetahuan yang biasa dipelajari di sekolah. Ilmu pengetahuan yang dipelajari saat sekolah harus disertai dengan hasil pengamatan atau penelitian yang salah satu caranya adalah melalui metode praktikum. Dilihat dari kemampuan siswa di sekolah tersebut, khususnya dalam mata pelajaran fisika masih banyak siswa yang kurang memahami materi yang dijelaskan oleh guru. Apalagi apabila guru hanya menyampaikan materi dengan biasa saja dan tidak mengkolaborasikan materi dengan kehidupan sehari-hari. Sehingga jika dengan cara seperti itu akan tetap dilakukan oleh guru maka pikiran serta pemahaman siswa terhadap materi yang disampaikan oleh guru tidak akan bisa diserap secara mendalam.

Oleh karena itu, perlu dilakukan sesuatu pembelajaran yang berbeda dari biasa, seperti pembelajaran yang melibatkan siswa dalam sebuah praktik atau eksperimen. Sehubungan dengan permasalahan tersebut dibutuhkan strategi pembelajaran yang tepat untuk meningkatkan hasil belajar dan keterampilan proses sains siswa. Salah satunya adalah dengan pemebelajaran dengan menggunakan metode praktikum berbasis inkuiri. Metode praktikum paling tepat digunakan untuk merealisasikan pembelajaran dengan pendekatan inkuiri dan pembelajaran dengan metode praktikum.

\section{Metode Penelitian}

Jenis penelitian yang digunakan dalam penelitian adalah penelitian tindakan kelas (PTK). Penelitian tindakan kelas (PTK) merupakan bentuk penelitian tindakan yang diterapkan dalam aktivitas pembelajaran dikelas. Ciri khusus PTK yaitu adanya tindakan nyata yang dilakukan sebagai kegiatan peneliti dalam memecahkan masalah. Penelitian Tindakan Kelas merupakan proses pengkajian suatu masalah pembelajaran yang di dalam kelas dengan diawali dengan refleksi dengan upaya untuk memecahkan masalah dengan cara melakukan tindakan yang direncanakan dalam situasi yang nyata untuk menganalisis setiap pengaruh dari permasalahan tersebut. Istrumen yang digunakan dalam penelitian ini adalah berupa tes untuk memperoleh hasil belajar dan lembar observasis aspek afektif dan psikomotorik untuk memperoleh hasil keterampilan proses sains siswa.

Adapun desain penelitian yang digunakan adalah :

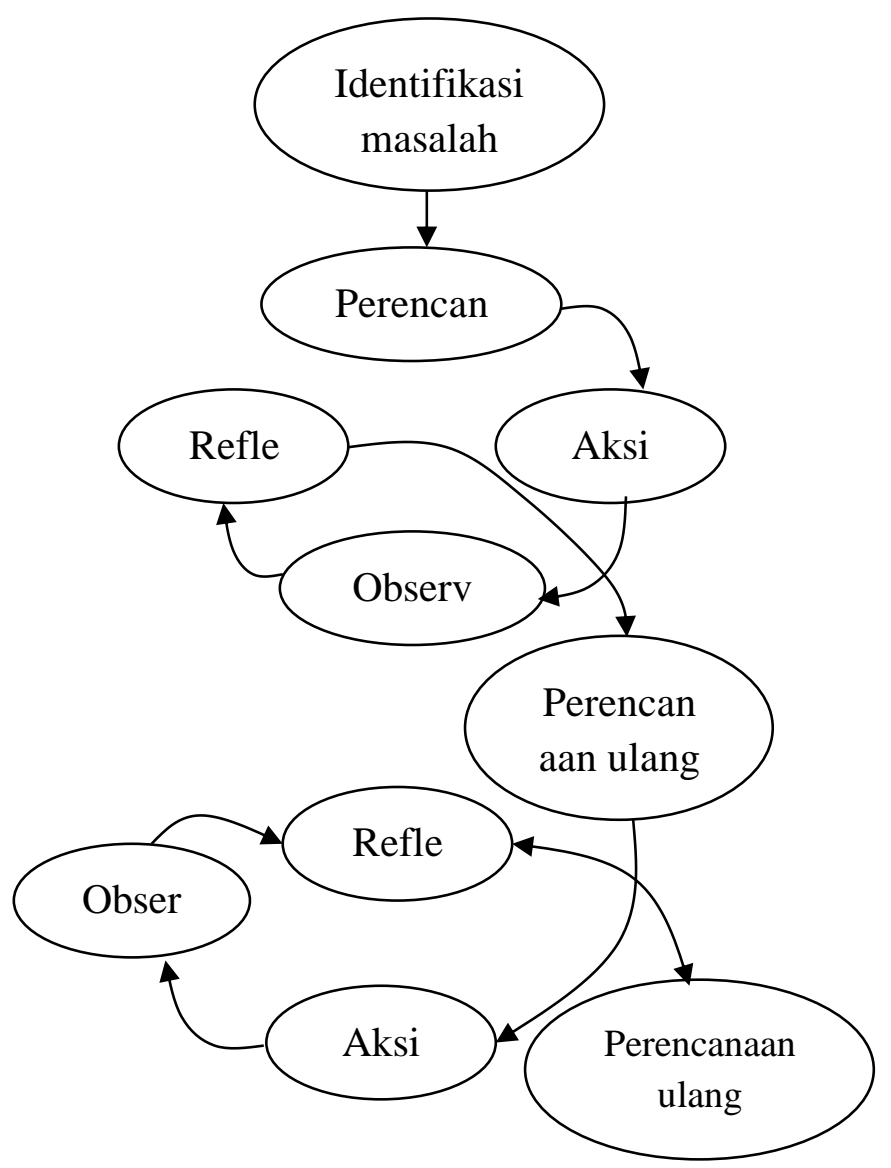




\section{Hasil Penelitian dan Pembahasan}

Penelitian ini merupakan Penelitian Tindakan Kelas (PTK), dimana PTK merupakan bentuk penelitian tindakan yang diterapkan dalam aktivitas pembelajaran dikelas. Penelitian Tindakan Kelas merupakan proses pengkajian suatu masalah pembelajaran yang didalam kelas diawali refleksi untuk memecahkan masalah dengan cara melakukan tindakan yang direncanakan dalam situasi yang nyata untuk menganalisis setiap pengaruh dari permasalahan tersebut. Penelitian Tindakan Kelas (PTK) ini dilaksanakan dalam 2 siklus, masing-masing siklus dilaksanakan sebanyak 2 kali pertemuan.

Sebelum memulai pembelajaran hendaknya terlebih dahulu mengetahui kemampuan awal siswa yang akan diteliti. Kemampuan awal siswa dapat dilihat dengan mengadakan pre-test. Selanjutya dilakukan penilaian secara keseluruhan untuk keterampilan proses sains dan hasil belajar siswa untuk masing-masing siklus dan dilihat perbandingan kedua siklus tersebut.

Tabel 1: Rekapitulasi Hasil Keterampilan Proses Sains Siklus I

\begin{tabular}{ccc}
\hline No & Jenis Data & $\begin{array}{c}\text { Hasil yang } \\
\text { Diperoleh }\end{array}$ \\
\hline 1 & Nilai Terendah & 69.68 \\
2 & Nilai Tertinggi & 85.31 \\
3 & Nilai Rata-rata & 77.61 \\
4 & Jumlah siswa dengan kategori kurang & - \\
5 & Jumlah siswa dengan kategori cukup & 11 orang \\
6 & Jumlah siswa dengan katgori baik & 20 orang \\
7 & Jumlah siswa dengan kategori sangat & 1 orang \\
& baik \\
\hline
\end{tabular}

Keterampilan proses sains siswa aspek psikomotorik sudah memenuhi kriteria ketercapaian indikator. Hal ini dibuktikan dengan hasil rata-rata nilai yang diperoleh siswa termasuk dalam kategori cukup, baik dan sangat baik. Nilai terendah siswa adalah 69.68, nilai tertinggi siswa adalah 85.31 dan nilai rata-ratanya adalah 77.61. Siswa yang masuk kategori cukup berjumlah 11 orang, kategori baik 20 orang dan sangat baik masing-masing adalah 1 orang.
Tabel 2: Rekapitulasi Hasil Keterampilan Proses Sains Siklus II

\begin{tabular}{ccc}
\hline No & Jenis Data & $\begin{array}{c}\text { Hasil yang } \\
\text { Diperoleh }\end{array}$ \\
\hline 1 & Nilai Terendah & 68.12 \\
2 & Nilai Tertinggi & 86.87 \\
3 & Nilai Rata-rata & 78.20 \\
4 & Jumlah siswa dengan kategori kurang & - \\
5 & Jumlah siswa dengan kategori cukup & 6 orang \\
6 & Jumlah siswa dengan katgori baik & 24 orang \\
7 & Jumlah siswa dengan kategori sangat & 2 orang \\
\hline
\end{tabular}

Ketercapaian keterampilan proses sains pada siklus II ini sudah sangat baik dan mencapai kriteria yaitu dengan rata-rata 78.20. Nilai terendah adalah 68.12 dan nilai tertingginya adalah 86.87. Pada siklus II ini tidak ada siswa dengan kategori kurang.

Tabel3: Ringkasan Nilai Post-Test Siswa Siklus I

\begin{tabular}{ccc}
\hline No & Jenis Data & $\begin{array}{c}\text { Hasil yang } \\
\text { Diperoleh }\end{array}$ \\
\hline 1 & Nilai Terendah & 60 \\
2 & Nilai Tertinggi & 95 \\
3 & Nilai Rata-rata & 81.71 \\
4 & Jumlah Siswa yang Tuntas & 27 Orang \\
5 & Jumlah Siswa yang Tidak Tuntas & 5 Orang \\
6 & Persentase Ketuntasan & $81.71 \%$ \\
7 & Persentase Ketidaktuntasan & $18.29 \%$ \\
\hline
\end{tabular}

Tabel 4: Ringkasan Nilai Post-Test Siswa Siklus II

\begin{tabular}{ccc}
\hline No & Jenis Data & $\begin{array}{c}\text { Hasil yang } \\
\text { Diperoleh }\end{array}$ \\
\hline 1 & Nilai Terendah & 70 \\
2 & Nilai Tertinggi & 100 \\
3 & Nilai Rata-rata & 91.25 \\
4 & Jumlah Siswa yang Tuntas & 31 Orang \\
5 & Jumlah Siswa yang Tidak Tuntas & 1 Orang \\
6 & Persentase Ketuntasan & $91.25 \%$ \\
7 & Persentase Ketidaktuntasan & $8.75 \%$ \\
\hline
\end{tabular}

Dari hasil post-test siklus II diperoleh hasil bahwa nilai rata-rata siswa mencapai 91.25. Hal ini meningkat jika dibandingkan dengan nilai yang diperoleh pada siklus I. Sementara untuk jumlah siswa yang tidak tuntas berjumlah 1 orang saja. Sedangkan untuk persentase ketuntasan mencapai $91.25 \%$.

\section{Keterampilan Proses Sains}

Keterampilan proses sains merupakan keterampilan yang didalamnya terdapat kemampuan fisik dan mental yang yang berkaitan dengan kemampuan dasar yang dimiliki sehingga seseorang berhasil mendapatkan sesuatu yang baruKeterampilan proses sains yang dimaksud adalah aspek psikomotorik dan aspek afektif. 
Pada siklus I dilakukan pembelajaran dengan metode praktikum berbasis inkuiri. Metode praktikum paling tepat digunakan untuk merealisasikan model pembelajaran inkuiri atau model pembelajaran berdasarkan penemuan. Pembelajaran inkuiri yang digabungkan dengan metode praktikum mampu memberikan dampak yang positif bagi hasil belajar siswa. Pada siklus I ini

\begin{tabular}{cccc}
\hline No & Siklus & $\begin{array}{c}\text { Jumlah Siswa } \\
\text { yang Tuntas } \\
\text { Belajar } \\
\text { Setelah } \\
\text { Diperoleh } \\
\text { Nilai Akhir }\end{array}$ & $\begin{array}{c}\text { Ketuntasan Klasikal } \\
\text { ISiswa yang tuntas }\end{array}$ \\
& & $P=\frac{N}{100 \%}$ \\
\hline 1 & I & 27 & $84.37 \%$ \\
2 & II & 31 & $96.87 \%$
\end{tabular}

pembelajaran dilakukan sebanyak 2 kali pertemuan, yaitu pertemuan I dan pertemuan II. Nilai yang diperoleh dari pertemuan I dengan penggolongan siswa berdasarkan kategori cukup, baik dan sangat baik. Nilai terendah siswa 69.68, nilai tertinggi siswa 85.31 dan nilai rata-rata 77.61. Untuk siswa yang tergolong dalam kategori kurang tidak ada, artinya tidak satupun siswa yang masuk dalam kategori tersebut. Siswa yang masuk kategori cukup sebanyak 11 orang, dalam kategori baik sebanyak 20 orang dan sangat baik masing-masing adalah 1 orang.

Pada siklus II juga dilakukan penelitian dengan menggunakan metode praktikum berbasis inkuiri seperti halnya pada siklus I. Ketercapaian proses sains aspek psikomotorik siswa pada siklus II ini sudah sangat baik dan mencapai kriteria yaitu dengan nilai rata-rata 78.20 , nilai terendah adalah 68.12 dan nilai tertinggi adalah 86.87. Pada siklus II ini tidak ada siswa dengan kategori kurang. Sedangkan jumlah siswa dengan kategori cukup sebanyak 6 orang, kategori baik sebanyak 24 orang dan kategori sangat baik sebanyak 2 orang.

\section{Hasil Belajar}

Hasil belajar yang dimaksud adalah hasil penilaian dari aspek kognitif. Hasil belajar tidak hanya pengetahuan konsep saja, akan tetapi pengetahuan tentang keterampilan menganalisis dan memecahkan suatu permasalahan.

Dari post-test siklus I diperoleh hasil rata-rata nilai siswa dikelas 81.71 dengan jumlah siswa yang tuntas sebanyak 27 orang dengan persentase ketuntasannya mencapai
$81.71 \%$. Hasil yang diperoleh disiklus I ini sudah memenuhi target ketercapaian. Sedangkan hasil post-test siklus II diperoleh hasil bahwa nilai rata-rata siswa mencapai 91.25 hal ini terjadi peningkatan jika dibandingkan dengan nilai yang diperoleh pada siklus I. Sementara untuk jumlah siswa yang tidak tuntas (tidak lulus KKM) berjumlah 1 orang saja pada siklus II, mengalami penurunan jika dibandingkan dengan dengan siklus I yang berjumlah 5 orang. Sedangkan untuk persentase ketuntasan pada siklus II mencapai $91.25 \%$.

Hasil Analisis Ketuntasan Klasikal Keseluruhan Siklus I dan II

Dari data diatas dapat diketahui bahwa secara umum dari siklus I sudah menunjukkan hasil ketercapaian target. Namun setelah dilakukan kembali disiklus II terjadi peningkatan nilai meskipun tidak banyak. Hal tersebut juga berpengaruh terhadap ketuntasan klasikal kelas XI IPA 2 dari $84.37 \%$ pada siklus I menjadi $96.87 \%$ pada siklus II. Hal ini menunjukkan bahwa metode yang digunakan telah sesuai, sehingga dapat dikatakan penelitian ini berhasil sesui kriteria indikator ketercapaian yang telah ditetapkan sebelumnya.

\section{Kesimpulan dan Rekomendasi}

Penerapan metode praktikum berbasis inkuiri dapat meningkatkan hasil belajar siswa pada pelajaran fisika topik getaran dan gelombang yang dibuktikan dengan nilai ratarata test pada siklus 81.71 meningkat pada siklus II dengan nilai rata-rata 91.25. Hal tersebut dapat dibuktikan juga dengan ketuntasan klasikal siswa pada siklus I mencapai $84.37 \%$ sedangkan pada siklus II meningkat menjadi $96.87 \%$.

Penerapan metode praktikum berbasis inkuiri dapat meningkatkan keterampilan proses sains siswa pada pelajaran fisika topik getaran dan gelombang yang dibuktikan dengan nilai rata-rata keterampilan proses sains siswa pada siklus I yaitu 77.61 sedangkan pada siklus II mencapai 78.20.

\section{Daftar Pustaka}

Dedi Holde Simbolon dan Sahyar. (2015). Pengaruh Model Pembelajaran Inkuiri 
Terbimbing Berbasis Eksperimen Riil dan Laboratorium Virtual Terhadap Hasil

Belajar Fisika Siswa, Vol.21 (No.3), hlm.3.

Indri Pratiwi dkk.Pengaruh Metode Praktikum Menggunakan KIT optic Terhadap hasil Belajar Siswa Pada Pokok bahasan cahaya di Kelas VIII SMP Negeri 1 Prabumulih. hlm.1.

Kurnia Rizky dkk. (2016). Efektivitas Pembelajaran Praktikum Berbais Inkuiri Terbimbing Terhadap Gerak Adaptif (Keterampilan) Mata Pelajaran Fisika. Vol.4 (No.2), hlm.1.

Nuraini Fatmi dan Sahyar. (2014). Pengaruh Model Pembelajaran Inkuiri Terbimbing dan Kreativitas Terhadap Keterampilan Proses Sains Siswa SMA. Vol.3. (No.1), hlm.3.

Ria Rahmawati dkk. (2014). Penerapan Praktikum Berbasis Inkuiri Untuk Meningkatkan
Keterampilan Proses Sains Siswa. Vol.8. (No.4), hlm.2.

Ramayulis. (2002). Ilmu Pendidikan Islam. Jakarta: Kalam Mulia.

SMAN 1 Pringgarata, Observasi Tanggal 29 Januari 2019, pukul 09.00 Wita.

Supardi dan Suhardjono. (2011). Strategi Menyusun Penelitian Tindakan Kleas. Yogyakarta: Penerbit Andi.

Trianto. (2010). Model Pembelajaran Terpadu. Jakarta: Bumi Aksara.

Wina Sanjaya. (2010). Penelitian Tindakan Kelas. Jakarta: Kencana Prenada Media Group.

Wiwin Ambarsari dkk. (2013). Penerapan Pembelajaran Inkuiri Terbimbing Terhadap Keterampilan Proses Sains Siswa Dasar Pada Pelajaran Biologi Siswa Kelas VIII SMP Negeri 7 Surakarta. Vol.5 (No.1), hlm.2. 